\title{
ANALISIS CAR, BOPO, NPF, FDR, NOM, DAN DPK \\ TERHADAP PROFITABILITAS (ROA) PADA BANK SYARIAH DI INDONESIA
}

\author{
Abdul Karim \\ Abdulkarimbutarbutar@gmail.com \\ Universitas Muhammadiyah Tangerang \\ Fifi Hanafia \\ Fifihanafia77@gmail.com \\ Universitas Pelita Bangsa Bekasi
}

\begin{abstract}
Abstrak
Tujuan daripada penelitian ini untuk mengetahui seberapa besar pengaruh CAR, BOPO, NPF, FDR, NOM dan DPK terhadap ROA pada BUS dan selama 5 tahun terakhir. Data yang digunakan dalam penelitian ini berupa data sekunder, yang dikumpulkan bersifat cross section. Data dalam penelitian ini diperoleh dari laporan keuangan Bank Umum Syariah dan Bank Pembiayaan Rakyat Syariah baik yang diterbitkan oleh masing-masing website Bank Umum Syariah dan Bank Pembiayaan Rakyat Syariah maupun yang diterbitkan oleh Bank Indonesia. Sampel yang diambil sebanyak 10 Bank Umum Syariah. Teknik pengambilan data dengan cara purposive sampling. Data yang diperoleh kemudian diolah dengan menggunakan alat bantu SPSS 22. Teknik analisis ini menggunakan uji regresi linier berganda.

Hasil regresi berganda menunjukkan bahwa CAR tidak berpengaruh terhadap ROA pada BUS, CAR berpengaruh positif terhadap ROA pada BPRS, BOPO berpengaruh negatif terhadap ROA pada BUS dan BPRS, NPF berpengaruh positif terhadap ROA pada BUS, NPF berpengaruh negatif terhadap ROA pada BPRS, FDR tidak berpengaruh terhadap ROA pada BUS, FDR berpengaruh negatif terhadap ROA pada BPRS, NOM berpengaruh positif terhadap ROA pada BUS, NOM tidak berpengaruh terhadap ROA , DPK tidak berpengaruh terhadap ROA pada BUS .
\end{abstract}

Kata Kunci: ROA, CAR, BOPO, NPF, FDR, NOM, dan DPK

\section{Pendahuluan}

Menghadapi perkembangan dunia usaha perbankan yang dinamis, maka bank dalam menciptakan produk dan jasa perbankan harus memperhatikan kebutuhan dan keinginan masyarakat. Masyarakat selalu menginginkan suatu produk atau jasa yang dapat memperlancar segala keperluan mereka dengan sarana yang lebih banyak dan praktis serta didukung dengan adanya pelayanan yang lebih baik dan cepat. Informasi yang dibutuhkan pasar sebagai potential user dan pihak-pihak yang berkepentingan dengan perusahaan bukan hanya informasi produk tetapi juga berbagai hal yang terkait dengan perusahaan. Salah satu informasi tersebut adalah kondisi keuangan atau yang sering disebut sebagai laporankeuangan

Saat ini pertumbuhan perbankan di Indonesia mengalami kemajuan yang pesat. Hal ini terjadi pada Bank Konvensional maupun Bank Syariah. Pada masa mendatang minat masyarakat Indonesia untuk menggunakan bank syariah akan semakin tinggi dan mampu meningkatkan signifikansi peran Bank Syariah dalam mendukung stabilitas sistem keuangan nasional. Hal tersebut dapat dilihat pada data statistikberikut: 


\begin{tabular}{|l|r|r|r|r|r|r|}
\hline \multirow{2}{*}{ Keterangan } & \multicolumn{6}{|c|}{ Pertumbuhan Bank Syariah per tahun } \\
\cline { 2 - 8 } & $\mathbf{2 0 1 3}$ & $\mathbf{2 0 1 4}$ & $\mathbf{2 0 1 5}$ & $\mathbf{2 0 1 6}$ & $\mathbf{2 0 1 7}$ & $\mathbf{2 0 1 8}$ \\
\hline Bank Umum Syariah & 11 & 12 & 12 & 13 & 13 & 13 \\
\hline Unit Usaha Syariah & 23 & 22 & 22 & 21 & 21 & 21 \\
\hline $\begin{array}{l}\text { Bank Pembiayaan Rakyat } \\
\text { Syariah }\end{array}$ & 163 & 163 & 163 & 166 & 167 & 167 \\
\hline
\end{tabular}

Sumber: www.ojk.go.id

Tabel di atas menunjukkan bahwa dari tahun ke tahun jumlah bank mengalami kenaikan. Hal itu terjadi pada Bank Umum Syariah maupun Bank Pembiayaan Rakyat Syariah.

Bank Indonesia telah menetapkan salah satu ukuran profitabilitas suatu bank adalah Retuen On Assets (ROA). ROA penting bagi bank karena ROA digunakan untuk mengukur efektifitas perusahaan di dalam menghasilkan keuntungan dengan memanfaatkan aktiva yang dimiliki (Endraswati, 2018). Perusahaan dengan profitabilitas yang baik menunjukkan perusahaan mempunyai prospek yang baik, perusahaan akan mampu mempertahankan kelangsungan perusahaan dalam jangka panjang (Almunawwaroh \& Marliana, 2018).

Dalam penelitian Yusuf (2017) yang berjudul Dampak Indikator Rasio Keuangan terhadap Profitabilitas Bank Umum Syariah di Indonesia pada tahun 2012-2014, dengan menggunakan rasio keuangan berupa FDR, NPF, BOPO dan Ukuran perusahaan pada 11 Bank Umum Syariah. Dapat disimpulkan bahwa FDR, NPF, BOPO memiliki pengaruh positif terhadap ROA, sedangkan Ukuran tidak berpengaruh terhadap Return On Assets (ROA) pada Bank Umum Syariah.

Menurut Mokoagow \& Fuady (2015) dalam penelitian Faktor- Faktor yang mempengaruhi Profitabilitas Bank Umum Syariah di Indonesia yang dilakukan adalah difokuskan pada penggunaan variabel CAR, KAP, REO, FDR, dan GWM untuk mengetahui pengaruhnya terhadap profitabilitas Bank Syariah di Indonesia sebanyak 6 bank. Hasilnya menunjukkan bahwa pada variabel FDR, dan GWM tidak berpengaruh terhadap ROA pada Bank Umum Syariah. Disisi lain, hasil penelitian menunjukkan bahwa CAR, KAP dan REO berpengaruh negatif terhadap ROA pada Bank Umum Syariah.

\section{Landasan Teori}

Beberapa pengertian dan penelitian yang mendukung ini yang sudah di teliti sebelumnya dan beberapa pendapat para ahli sebagai referensi dan memiliki kesamaan dalam penelitian

Menurut Sabir, Muhammad \& Habbe (2017) melakukan penelitian pada Bank Umum Syariah dan Bank Konvensional. Rasio yang digunakan Capital Adequacy Ratio (CAR), Biaya Operasional terhadap Pendapatan Operasional (BOPO), Net Operating Margin (NOM), Non Performing Financing (NPF), Financing to Deposit Ratio (FDR), Net Interest Margin (NIM), Non Performing Loan (NPL), dan Loan to Deposit Ratio (LDR). Hasil penelitian menunjukkan bahwa BOPO berpengaruh negatif signifikan terhadap ROA, NOM berpengaruh positif signifikanterhadap ROA, NPF tidak berpengaruh terhadap ROA dan FDR berpengaruh positif dan signifikan terhadap ROA.

Menurut Rizal (2016) dalam penelitian Pengaruh Capital Adequacy Ratio (CAR), Non Performing Finance (NPF) dan Operational Efficiency Ratio (OER) terhadap Profitabilitas (ROA) Bank Pembiayaan Rakyat Syariah periode 2012-2015. Hasil uji menunjukkan bahwa CAR tidak berpengaruh terhadap ROA pada BPRS. NPF dan OER 
berpengaruh negatif dan signifikan terhadap ROA pada BPRS. Secara simultan CAR, NPF dan OER berpengaruh dan signifikan terhadap ROA padaBPRS.

Husaeni (2017) melakukan penelitian pada Bank Pembiayaan Rakyat Syariah di Indonesia dengan menggunakan sampel sebanyak 30 data. Analisa yang digunakan adalah pengaruh Dana Pihak Ketiga dan Non Performing Financing (NPF) terhadap Return on Assets (ROA). Hasil penelitian menunjukkan bahwa secara Dana Pihak Ketiga (DPK) secara parsial berpengaruh negatif dan tidak signifikan terhadap variabel ROA. Sedangkan Variabel Non Performing Financing (NPF) secara parsial berpengaruh positif dan signifikan terhadap variabel ROA. Sedangkan secara simultan DPK dan NPF berpengaruh signifikan terhadapROA.

\subsection{Pengertian Profitabilitas BankSyariah}

Menurut Harmono (2009) profitabilitas merupakan suatu kemampuan yang menggambarkan kinerja fundamental perusahaan yang ditinjau dari tingkat efisiensi dan efektivitas operasi perusahaan dalam memperoleh keuntungan. Menurut Hasibuan (2008) bahwa profitabilitas bank adalah suatu kemampuan suatu bank untuk memperoleh keuntungan yang dinyatakan dalam persentase. Profitabilitas pada dasarnya adalah laba (Rupiah) yang dinyatakan dalam persen (\%) profit

\subsection{Pengertian Capital Adequacy Ratio(CAR)}

Capital Adequacy Rasio (CAR) merupakan rasio kinerja bank untuk mengukur kecukupan modal yang dimiliki oleh bank untuk menunjang aktiva yang menghasilkan resiko. Modal merupakan salah satu faktor penting dalam rangka pengembangan usaha bisnis dan menampung resiko kerugian, semakin tinggi CAR maka semakin kuat kemampuan banktersebut untuk menanggung resiko dari setiap Pinjaman/aktiva produktif yang berisiko.

\subsection{Pengertian Biaya Operasional per Pendapatan Operasional(BOPO)}

Variabel BOPO (Biaya Operasional Pendapatan Operasional) terkait dengan efisiensi beban manajemen yang dianggap menjadi salah satu faktor penentu yang penting dari profitabilitas perbankan karena ada kemungkinan bagi bank-bank untuk meningkatkan profitabilitas dengan memfokuskan perhatian pada pengendalian biaya yang tepat dan efisiensi operasi.

Kriteria Penilaian BOPO

\begin{tabular}{|l|l|}
\hline Kriteria & Keterangan \\
\hline Peringkat 1: $\mathrm{BOPO} \leq 83 \%$ & Sangat Rendah \\
\hline Peringkat 2: $83 \%<\mathrm{BOPO} \leq 85 \%$ & Cukup Rendah \\
\hline Peringkat 3: $85 \%<\mathrm{BOPO} \leq 87 \%$ & Rendah \\
\hline Peringkat 4: $87 \%<\mathrm{BOPO} \leq 89 \%$ & Cukup Timggi \\
\hline Peringkat 5: $\mathrm{BOPO}>90 \%$ & Tinggi \\
\hline
\end{tabular}

\subsection{Pengertian Non-Performing Financing (NPF)}

Rasio pembiayaan bermasalah digunakan sebagai pengukur tingkat kegagalan pengembalian kredit atau pembiayaan oleh bank selaku kreditur. NPF lebih dikenal dengan nama Non Performing Loan (NPL). Dalam peraturan Bank Indonesia Nomor 6/10/PBI/2004 tanggal 12 April 2004 tentang Sistem Penilaian Tingkat Kesehatan Bank Umum, semakin tinggi nilai NPL (diatas 5\%) maka bank tersebut tidak sehat, sehingga, semakin tinggi NPF maka semakin buruk kualitas kredit bank yang menyebabkan jumlah kredit bermasalah semakin besar 
Pembiayaan bermasalah merupakan resiko penyaluran dana. Kriteria penilaian tingkat NPF adalah <2\% pada kategori lancar, 2\%-5\% pada kategori dalam perhatian khusus, 5\%-8\% pada kategorikuranglancar,8\%-12\% padakategoridiragukandan $>12 \%$ pada kategori macet. Golongkan pembiayaan bermasalah ada pada kategori kurang lancar, diragukan dan macet (Nurvarida, 2017)

\subsection{Pengertian Financing to Deposit Ratio(FDR)}

Rasio Financing to Deposit Ratio (FDR) yaitu jumlah pendanaan yang dikeluarkan oleh bank syariah untuk mendukung investasi yang telah direncanakan selama waktu tertentu dari hasil penghimpunan dana pihak ketiga (Harjanti \& Mahmudah, 2016).

Financing to Deposit Ratio (FDR) dapat mempengaruhi tingkat profitabilitas Bank Syariah (Sumarlin, 2016). Dalam Surat Edaran Bank Indonesia Nomor 26/5/BPPP tanggal 2 Mei 1993, besarnya FDR ini ditetapkan oleh Bank Indonesia tidak boleh melebihi $110 \%$. Semakin tinggi FDR maka semakin tinggi dana yang disalurkan ke dana pihak ketiga. Dengan dana pihak ketiga yang disalurkan maka pendapatan atau profitabilitas semakin meningkat (Sumarlin, 2016).

\subsection{Pengertian Net Operating Margin(NOM)}

NOM adalah rasio yang digunakan untuk mengukur kemampuan manajemen bank dalam menghasilkan pendapatan dari bunga dengan melihat kinerja bank dalam menyalurkan pinjaman, mengingat pendapatan operasional bank sangat tergantung dari selisih bunga dari pinjaman yang disalurkan. Menurut Surat Edaran BI No. 3/30DPNP tanggal 14Desember 2001, NOM diukur dari perbandingan antara pendapatan bunga bersih terhadap aktiva produktif (Wibisono \& Wahyuni, 2017).

\subsection{Pengertian Dana Pihak Ketiga (DPK)}

Dana pihak ketiga adalah dana yang diperoleh dari masyarakat baik perorangan maupun badan usaha yang diperoleh bank dengan menggunakan berbagai instrument produk simpanan yang dimiliki oleh bank (Harjanti \& Mahmudah, 2016) Menurut Peraturan Bank Indonesia No. 10/19/PBI/2008 Dana Pihak Ketiga adalah kewajiban bank kepada penduduk dalam rupiah dan valuta asing. Umumnya dana yang dihimpun oleh perbankan dari masyarakat akan digunakan untuk pendanaan aktivitas sektor riil melalui penyaluran kredit.

Dana Pihak Ketiga dalam Perbankan Syariah merupakan sumber dana yang berasal dari masyarakat yang terhimpun melalui produk giro, wadiah, tabungan mudharabah dan deposito mudharabah. Dana Pihak Ketiga yang dimiliki Perbankan Syariah akan disalurkan ke berbagai jenis pembiayaan (Husaeni, 2017). Menurut Arifin (2006) dalam Husaeni (2017), yang termasuk dalam dana pihak ketiga yaitu: giro, tabungan dan deposito. 


\subsection{Kerangka Penelitian}

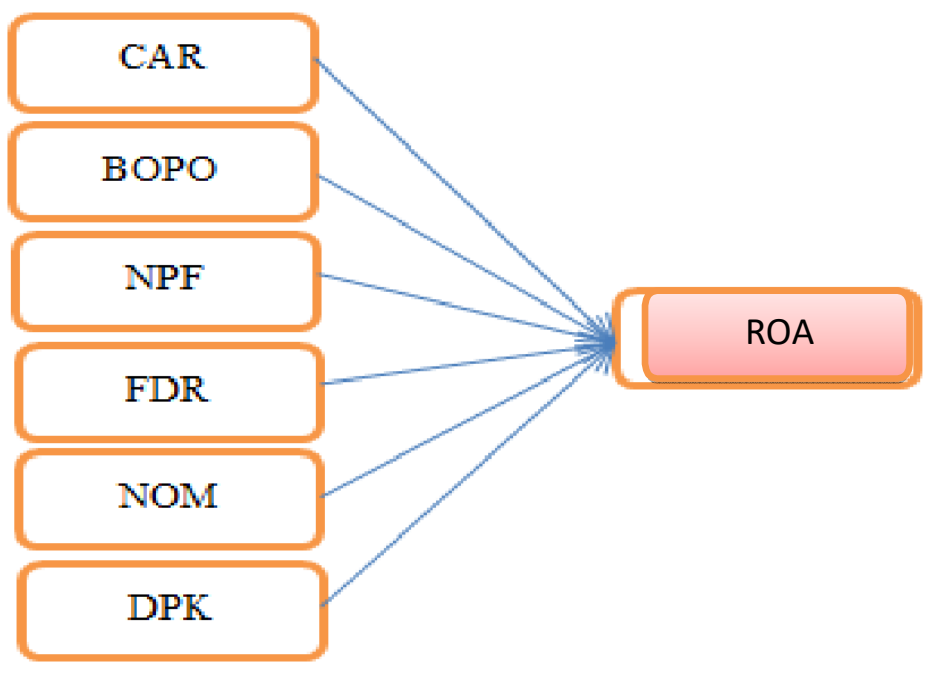

3. Metode Penelitian

3.1. Jenis Penelitian

Jenis penelitian ini adalah penelitian kuantitatif. Menurut Noor (2011), penelitian kuantitatif merupakan metode untuk menguji teori-teori tertentu dengan cara meneliti hubungan antar variabel. Dalam hal ini, teori menjadi faktor yang sangat penting dalam proses penelitian dan menggunakan data data yang tersedia sesuai dengan laporan keuangan dengan berbagai sumber penunjang.

\subsection{Lokasi dan WaktuPenelitian}

Data yang digunakan dalam penelitian ini adalah berupa data sekunder yang dikumpulkan dari institusi maupun penerbitan dari lembaga nasional berupa data yang bersifat cross section. Data dalam penelitian ini diperoleh dari laporan keuangan Bank Umum Syariah dan Bank Pembiayaan Rakyat Syariah baik yang diterbitkan oleh masing-masing website Bank Umum Syariah dan Bank Pembiayaan Rakyat Syariah maupun yang diterbitkan oleh Bank Indonesia.

\subsection{Teknik PengumpulanData}

Data yang digunakan dalam penelitian ini merupakan data sekunder yakni laporan keuangan Bank Umum Syariah dan Bank Pembiayaan Rakyat Syariah di Indonesia yang telah dipublikasikan baik melalui website resmi Bank Indonesia maupun websitemasing-masing

Bank Umum Syariah dan Bank Pembiayaan Rakyat Syariah pada tahun 2013 2018. Data mengenai variabel independen dan variabel dependen Bank Umum Syariah diperoleh dengan mengakses masing-masing webiste Bank Umum Syariah berupa Annual Report, sedangkan untuk data mengenai variabel dependen dan independen Bank Pembiayaan Rakyat Syariah diperoleh dari laporan keuangan yang diterbitkan oleh Bank Indonesia. Adapun teknik pengumpulan data yang dilakukan ialah dengan studi pustaka atau dokumentasi yakni dengan menggunakan atau mengumpulkan beberapa literatur yang mendukung penelitian ini. 


\subsection{Populasi danSampel}

Populasi yang digunakan dalam penelitian ini adalah seluruh Bank Umum Syariah dan Bank Pembiayaan Rakyat Syariah yang berada di Indonesia dan terdaftar di website Bank Indonesia dan masuk dalam data statistik OJK. Jumlah populasi sebanyak 13 Bank Umum Syariah dan 24 Provinsi yang memiliki Bank Pembiayaan Rakyat Syariah. Pemilihan sampel dilakukan secara tidak acak, tidak semua elemen-elemen populasi terpilih menjadi sampel yaitu dengan cara purposivesampling.

Daftar Sample Bank Syariah Di Indonesia

\begin{tabular}{|c|c|}
\hline No & Nama Bank Syariah \\
\hline 1 & PT. Bank Aceh Syariah \\
\hline 2 & PT. Bank Muamalat Indonesia \\
\hline 3 & PT. Bank Victoria Syariah \\
\hline 4 & PT. Bank BRISyariah \\
\hline 5 & PT. Bank Jabar Banten Syariah \\
\hline 6 & PT. Bank BNI Syariah \\
\hline 7 & PT. Bank Syariah Mandiri \\
\hline 8 & PT. Bank Mega Syariah \\
\hline 9 & PT. Bank Panin Dubai Syariah \\
\hline 10 & PT. Bank Syariah Bukopin \\
\hline 11 & PT. BCA Syariah \\
\hline 12 & PT. Bank Tabungan Pensiunan Nasional Syariah \\
\hline 13 & PT. Maybank Syariah Indonesia \\
\hline \multicolumn{2}{|r|}{ Daftar Sampel Bank Umum syariah } \\
\hline No & Nama Bank Syariah \\
\hline & 1 PT. Bank Muamalat Indonesia \\
\hline & 2 PT. Bank Victoria Syariah \\
\hline & 3 PT. Bank BRISyariah \\
\hline & 4 PT. Bank Jabar Banten Syariah \\
\hline & 5 PT. Bank BNI Syariah \\
\hline & $\begin{array}{ll}6 & \text { PT. Bank Syariah Mandiri }\end{array}$ \\
\hline & \begin{tabular}{l|l}
7 & PT. Bank Mega Syariah \\
\end{tabular} \\
\hline & \begin{tabular}{l|l}
8 & PT. Bank Panin Dubai Syariah \\
\end{tabular} \\
\hline & 9 PT. Bank Syariah Bukopin \\
\hline & \begin{tabular}{l|l}
10 & PT. BCA Syariah \\
\end{tabular} \\
\hline
\end{tabular}

\subsection{Teknik Analisis}

Teknik analisis yang digunakan dalam penelitian ini analisis regresi berganda. Menurut Sarwono dan Suhayati (2010) Analisis regresi linier berganda yaitu suatu analisis yang digunakan secara bersamaan untuk meneliti pengaruh dua variabel atau lebih terhadap satu variabel yang tergantung dengan skala interval. Persamaan regresi yang digunakan adalah sebagai berikut:

\section{$\mathrm{ROA}=\mathrm{B}_{0}+\mathrm{B}_{1} \mathrm{CAR}+\mathrm{B}_{2} \mathrm{BOPO}+\mathrm{B}_{3} \mathrm{NPF}+\mathrm{B}_{4} \mathrm{FDR}+\mathrm{B}_{5} \mathrm{NOM}+\mathrm{B}_{6} \mathrm{DPK}+\mathrm{e}$}

Untuk menguji apakah variabel independen mempunyai pengaruh yang signifikan terhadap variabel dependen, maka diperlukan uji koefisien. Berikut uji koefisien yang dapat dilakukan untuk menguji pengaruh signifikansi antar variabel dependen dan variabel independen . 
4. Hasil Penelitian Dan Pembahasan

a. Statistik Deskriptif

Variabel-variabel yang dianalisis dalam penelitian ini meliputi: Return On aset (ROA), Capital Adequacy Ratio (CAR), Biaya Operasional per Pendapatan Operasional (BOPO), Non Performing Financing (NPF), Financing to Deposit Ratio (FDR), Net Operating Margin (NOM) dan Dana Pihak Ketiga (DPK). Statistik deskriptif variabel-variabel penelitian pada tabel berikut:

DescriptiveStatistics

\begin{tabular}{|l|r|r|r|r|r|}
\hline & $\mathrm{N}$ & $\begin{array}{c}\text { Minimu } \\
\mathrm{m}\end{array}$ & $\begin{array}{c}\text { Maximu } \\
\mathrm{m}\end{array}$ & Mean & Std. Deviation \\
\hline ROA & 50 & $-4,77$ & 4,33 &, 5324 & 1,40454 \\
CAR & 50 & 11,10 & 36,70 & 17,9932 & 5,52314 \\
BOPO & 50 & 68,47 & 217,40 & 98,8844 & 21,61029 \\
NPF & 50 &, 10 & 22,04 & 4,6718 & 4,19596 \\
FDR & 50 & 71,87 & 104,75 & 90,4242 & 7,01144 \\
NOM & 50 & $-27,84$ & 10,66 & 1,6674 & 5,69816 \\
DPK & 50 & 20,74 & 25,08 & 22,9404 & 1,25094 \\
Valid N & 50 & & & & \\
(listwise) & & & & & \\
\hline
\end{tabular}

Sumber : Output SPSS

Tabel menunjukkan dari 50 data variabel Return On Assets (ROA) memiliki nilai rata-rata sebesar $(0,5324)$ dengan standar deviasi sebesar (1,40454). Capital Adequacy Ratio (CAR) memiliki nilai rata-rata sebesar $(17,9932)$ dengan standar deviasi sebesar $(5,52314)$ , Biaya Operasional per Pendapatan Operasional (BOPO) memiliki nilai rata-rata sebesar $(98,8844)$ dengan standar deviasi sebesar $(21,61029)$, Non Performing Financing (NPF) memiliki nilai rata-rata sebesar $(4,6718)$

dengan standar deviasi sebesar $(4,19596)$, Financing to Deposit Ratio (FDR) memiliki nilai rata-rata sebesar $(90,4242)$ dengan standar deviasi sebesar $(7,01144)$, Net Operating Margin (NOM) memiliki nilai rata-rata sebesar $(0,5524)$ dengan standar deviasi sebesar $(1,33278)$ dan Dana Pihak Ketiga (DPK) memiliki nilai rata-rata sebesar $(0,5524)$ dengan standar deviasi sebesar $(1,33278)$.

\section{b. Uji Normalitas}

One-Sample Kolmogorov-Smirnov Test

\begin{tabular}{|ll|r|}
\hline & & \multicolumn{1}{|c|}{ Unstandardized Residual } \\
\hline $\mathrm{N}$ & & 50 \\
Normal & Mean & $0 \mathrm{E}-7$ \\
Parametersa,b & Std. Deviation &, 85195833 \\
Most & Absolute &, 155 \\
Extreme & Positive &, 155 \\
Differences & Negatif &,- 085 \\
Kolmogorov-Smirnov Z & 1,093 \\
Asymp. Sig. (2-tailed) &, 183 \\
\hline
\end{tabular}

Sumber: Output SPSS

Table diperoleh Asymp. Sig. (2-tailed) sebesar 0,183 > 0,05, maka dapat disimpulkan bahwa data telah lulus uji normalitas atau data berdistribusi normal. 


\section{c. Uji Multikolinearitas}

Uji multikolinearitas dilakukan dengan melihat nilai tolerance dan variance inflation factor (VIF). Hasil perhitungan uji multikolinearitas disajikan pada tabelberikut:

Coefficientsa $^{a}$

\begin{tabular}{|c|c|c|c|c|c|c|c|}
\hline \multirow[t]{2}{*}{ Model } & \multicolumn{2}{|c|}{$\begin{array}{l}\text { Unstandardized } \\
\text { Coefficients }\end{array}$} & \multirow{2}{*}{$\begin{array}{l}\begin{array}{l}\text { Standardize } \\
\text { d } \\
\text { Coefficients }\end{array} \\
\text { Beta }\end{array}$} & \multirow[t]{2}{*}{$\mathrm{t}$} & \multirow[t]{2}{*}{ Sig. } & \multicolumn{2}{|c|}{$\begin{array}{l}\text { Collinearity } \\
\text { Statistics }\end{array}$} \\
\hline & B & $\begin{array}{l}\text { Std. } \\
\text { Error }\end{array}$ & & & & $\begin{array}{c}\text { Toleranc } \\
\mathrm{e}\end{array}$ & VIF \\
\hline (Constant) & 2,014 & 4,651 & & ,433 & 667 & & \\
\hline CAR &, 045 & ,030 & ,177 & 1,501 & ,141 & 618 & 1,618 \\
\hline BOPO &,- 056 & ,009 &,- 856 & $-6,136$ & ,000 & ,440 & 2,273 \\
\hline NPF & ,153 & ,057 & ,458 & 2,709 & ,010 & ,300 & 3,336 \\
\hline FDR & ,005 & 021 & ,024 & 236 & ,815, & 806 & 1,241 \\
\hline NOM & ,078 & ,032 & ,316 & 2,469 & ,018 & ,521 & 1,919 \\
\hline DPK & ,084 & 129 & ,075 & 648 & ,520 & ,645 & 1,551 \\
\hline
\end{tabular}

a. Dependent Variable: ROA Sumber : Output SPSS

Tabel memperlihatkan bahwa tidak terdapat variabel bebas yang memiliki nilai tolerance kurang dari 0,1. Hasil perhitungan nilai variance inflation factor (VIF) menunjukkan tidak ada variabel bebas yang memiliki nilai VIF lebih dari 10. Nilai VIF variabel Capital Adequacy Ratio (CAR) sebesar $(1,618)$, Nilai VIF variabel Biaya Operasional per Pendapatan Operasional (BOPO) sebesar $(2,273)$, Nilai VIF variabel Non Performing Financing (NPF) sebesar (3,336), Nilai VIF variabel Financing to Deposit Ratio (FDR) sebesar $(1,241)$ Nilai VIF variabel Net Operating Margin (NOM) sebesar $(1,919)$ dan Nilai VIF variabel Dana Pihak Ketiga (DPK) sebesar $(1,551)$. Jadi dapat disimpulkan bahwa tidak ada multikoliearitas antar variabel bebas dalam modelregresi.

\section{d. Uji Heteroskedastisitas}

Ringkasan hasil uji heteroskedastisitas menggunakan uji White disajikan pada tabel berikut:

Model Summaryb

\begin{tabular}{|l|r|r|r|r|}
\hline Model & $\mathrm{R}$ & $\begin{array}{c}\mathrm{R} \\
\text { Square }\end{array}$ & $\begin{array}{c}\text { Adjusted } \mathrm{R} \\
\text { Square }\end{array}$ & $\begin{array}{c}\text { Std. Error of the } \\
\text { Estimate }\end{array}$ \\
\hline 1 &, $909 \mathrm{a}$ &, 827 &, 686 &, 93596 \\
\hline
\end{tabular}

a. Predictors: (Constant), X5_X6, FDR, CAR2, DPK, BOPO2, NOM2, NPF2,

$\mathrm{X} 1 \_\mathrm{X} 3, \mathrm{X} 1 \_\mathrm{X} 6, \mathrm{X} 1 \_\mathrm{X} 2, \mathrm{X} 1 \_\mathrm{X} 5, \mathrm{X} 1 \_\mathrm{X} 4, \mathrm{X} 2 \_\mathrm{X} 5, \mathrm{X} 3 \_\mathrm{X} 6$,

X3_X5, X4_X6, X2_X6, FDR2, X3_X4, CAR, DPK2,X2_X4

b. Dependent Variable: res2 Sumber : OutputSPSS

Dari persamaan regresi ini didapatkan nilai $\mathrm{R}^{2}$ untuk meghitung $\mathrm{c}^{2}$, dimana $\mathrm{c}^{2}=\mathrm{n}$ $x \mathrm{R}^{2}$ (Gujarati, 2003) dalam (Ghozali, 2013). Hasil dari $\mathrm{c}^{2}=50 x$ 0,827 yaitu sebesar 41,35. Menunjukkan bahwa $c^{2}$ hitung $(0,827)<c^{2}$ tabel $(67,40581)$, maka hipotesis alternatif heteroskedastisitas dalam model ditolak.

Dari persamaan regresi ini didapatkan nilai $\mathrm{R}^{2}$ untuk meghitung $\mathrm{c}^{2}$, dimana $\mathrm{c}^{2}=\mathrm{n}$ $x \mathrm{R}^{2}$ (Gujarati, 2003) dalam (Ghozali, 2013). Hasil dari $\mathrm{c}^{2}=145 x 0,785$ yaitu sebesar 113,825 . Menunjukkan bahwa $c^{2}$ hitung $(113,825)<c^{2}$ tabel $(124,34211)$, maka hipotesis alternatif heteroskedastisitas dalam model ditolak. 


\section{f. UjiAutokorelasi}

Pengujian autokorelasi dilakukan untuk mengetahui terdapat tidaknya korelasi berantai diantara faktor-faktor yang mengganggu secara berurutan. Dalam penelitian ini, metode pengujian dengan menggunakan nilai statistik Durbin Watson (DW). Untuk mengetahui ada tidaknya autokorelasi, dilakukan pengujian terhadap nilai DW dan dibandingkan nilai nilai $d_{U}$ dan $d_{L}$ dari tabel Durbin Watson. Untuk mengetahui ada dan tidaknya autokorelasi dapat dilihat pada tabel sebagai berikut:

Model Summary ${ }^{b}$

\begin{tabular}{|l|r|r|r|r|r|}
\hline Model & \multicolumn{1}{|c|}{$\mathrm{R}$} & $\begin{array}{c}\mathrm{R} \\
\text { Square }\end{array}$ & $\begin{array}{c}\text { Adjusted R } \\
\text { Square }\end{array}$ & $\begin{array}{l}\text { Std. Errorof } \\
\text { theEstimate }\end{array}$ & Durbin-Watson \\
\hline 1 &, 79 &, 632 &, 581 &, 90946 & 1,848 \\
5 & & & & \\
\hline
\end{tabular}

a. Predictors: (Constant), DPK, NPF, FDR, CAR, NOM, BOPO

b. Dependent Variable:ROA

Sumber : Output SPSS

Berdasarkan tabel 4.10 hasil pengujian autokorelasi untuk didapatkan nilai Durbin Watson sebesar 1,848. Sedangkan dari tabel Durbin Watson untuk $\square=5 \%$ dan sampel $n=$ 50, dan $k=6$ diperoleh nilai $\mathrm{d}_{\mathrm{L}}$ sebesar 1,2906 dan $\mathrm{d}_{\mathrm{U}}$ sebesar 1,8220. Karena nilai DW $(1,848)$ berada pada daerah antara $d_{U}$ sebesar 1,822 dan 4-du sebesar 2,178 maka dapat ditarik kesimpulan bahwa tidak terjadi Autokorelasi.

\section{g. Regresi Linier Berganda}

\section{Coefficients}

\begin{tabular}{|c|c|c|c|c|c|}
\hline \multirow[t]{2}{*}{ Model } & \multicolumn{2}{|c|}{$\begin{array}{c}\text { Unstandardized } \\
\text { Coefficients }\end{array}$} & $\begin{array}{l}\text { Standardize } \\
\text { d }\end{array}$ & $t$ & Sig. \\
\hline & B & Std. Error & Beta & & \\
\hline (Constant) & 2,014 & 4,651 & & 433 & 6 \\
\hline CAR & 045 & 030 & 177 & 1,501 & 1 \\
\hline BOPO &,- 056 & ,009 &,- 856 & $-6,136$ & ,00 \\
\hline NPF1 & 153 & 057 & ,458 & 2,709 & ,01 \\
\hline FDR & ,005 & ,021 & ,024 & ,236 & 8 \\
\hline $\mathrm{NOM}$ & 078 & ,032 & ,316 & 2,469 & 018 \\
\hline DPK & ,084 & ,129 & ,075 & 648 &, 52 \\
\hline
\end{tabular}

a. Dependent Variable: ROA

Sumber: Output SPSS

Berdasarkan hasil perhitungan regresi pada tabel 4.13 diperoleh persamaan sebagai berikut:

ROA = 2,014 + 0,045 CAR - 0,056 BOPO + 0,153 NPF - 0,005 FDR+0,078 NOM + 0,084 DPK 
5. Kesimpulan berikut:

Berdasarkan hasil penelitian yang telah dilakukan diambil kesimpulan sebagai

1) Hasil pengujian Capital Adequacy Ratio (CAR) tidak pengaruh terhadap Return On Aset (ROA) pada Bank Umum Syariah(BUS).

2) Hasil pengujian Biaya Operasional per Pendapatan Operasional (BOPO) memiliki pengaruh negatif terhadap Return On Aset (ROA) pada Bank Umum Syariah(BUS).

3) Hasil pengujian Non Performing Financing (NPF) tidak berpengaruh terhadap Return On Aset (ROA) pada Bank Umum Syariah(BUS).

4) Hasil pengujian Financing to Deposit Ratio (FDR) memiliki pengaruh positit terhadap Return On Aset (ROA) pada Bank UmumSyariah

5) Hasil pengujian Net Operating Margin (NOM) memiliki pengaruh positif terhadap Return On Aset (ROA) pada Bank UmumSyariah.

6) Hasil pengujian Dana Pihak Ketiga (DPK) tidak berpengaruhterhadap Return On Aset (ROA) pada Bank Umum Syariah (BUS).

Berdasarkan hasil penelitian yang telah dilakukan, dapat disimpulkan bahwa masih terjadi inkonsistensi hasil. Yang berarti masih layak untuk melakukan penelitian kembali.

6. Saran

1) Untuk Penelitian selanjutnya sebaiknya seluruh Perbankan Syariah yang terdaftar di Bank Indonesia agar memperoleh sampel yangberbeda.

2) Untuk Penelitian selanjutnya sebaiknya menambah waktu / periode yang lebih lama sehingga pengamatan hasilnya dapatdibandingkan.

3) Untuk Penelitian selanjutnya diharapkan dapat menambah variabel lain untuk menemukan faktor- faktor yang dapat mempengaruhi Return On Assets (ROA) PerbankanSyariah

4) Untuk Penelitian selanjutnya di harapkan hasilnya lebih baik dan ada variasi dalam menentukan pola penelitian.

\section{Daftar Pustaka}

Ariyani, Desi. (2010). Analisis pengaruh CAR, FDR, BOPO, dan NPF terhadap Profitabilitas (ROA) pada PT Bank Muamalat Indonesia Tbk. Al- Perbankan yang Terdaftar di Bursa Efek Indonesia Periode 2006-2008). Fokus Ekonomi. Vol. 5, No. 2, Hal.104-123

Endraswati, H. (2018). Gender Diversity in Board of Directors and Firm Performance: A Study in Indonesia Sharia Banks. Review of Integrative Business and Economics Research, Vol. 7, Supplementary Issue 1

Harianto, Syawal. (2017). Rasio Keuangan dan Pengaruhnya terhadap Profitabilitas pada Bank Pembiayaan Rakyat Syariah di Indonesia. Jurnal Bisnis dan Manajemen Volume 7 (1), April 2017. P-ISSN: 2087-2038; E-ISSN: 2461-1182. Halaman 41 - 48 (Online). Di unduh Juni

2018.

Husaeni, Uus Ahmad. (2017). Analisis Pengaruh Dana Pihak Ketiga Dan Non Performing Finance Terhadap Return On Assets Pada BPRS Di Indonesia. EQUILIBRIUM: Jurnal Ekonomi Syariah Volume 5, Nomor 1, 2017, 1 - 16 P-ISSN: 2355-0228, E-ISSN: 25028316.

(journal.stainkudus.ac.id/index.php/equilibrium. Di unduh Juni 2018).

Mahmudah, Nur dan Harjanti, Ririh Sri. (2016). Analisi Capital Adequacy Ratio (CAR), Financing to Deposit Ratio (FDR), Non Performing Financing (NPF) dan Dana Pihak 
Ketiga terhadap tingkat profitabilitas Bank Umum Syariah periode 2011-2013. SENIT 2016 (Online). Di unduh Juni 2018.

Mismiwati. (2016). Pengaruh CAR, NIM, BOPO, LDR dan NPL terhadap ROA (studi pada PT. BPD SUMSEL BABEL) . I-Finance Vol. 2. No. 1. Juli 2016.

Mokoagow, Sri W dan Fuady, Misbach. (2015). Faktor-faktor yang mempengaruhi Profitabilitas (ROA) Bank Umum Syari'ah di Indonesia. JurnalEBBANK.

Noor, Juliansyah. (2011). Metodologi Penelitian: Skripsi, Tesis, Disertasi dan Karya Ilmiah. Jakarta : Prenadamedia Group.

Rizal, Fitra. (2016). Pengaruh Capital Adequacy Ratio, Non Performing Finance dan Operational Efficiency Ratio terhadap Profitablitas Bank Pembiayaan Rakyat Syariah. Muslim Heritage, Vol. 1, No. 1, Mei - Oktober 2016 (Online).

Sabir. M, Muh., Ali, Muhammad \& Habbe, Abd. Hamid. (2012). Pengaruh Rasio Kesehatan Bank Terhadap Kinerja Keuangan Bank Umum Syariah Dan Bank Konvensional Di Indonesia. Jurnal Analisis, Juni 2012, Vol.1 No.1 : 79 - 86.

Sarwono, J., \& Suhayati, E. (2010). Riset Akuntansi Menggunakan SPSS. Yogyakarta: Graha Ilmu.

Sumarlin. (2016). Analisis Pengaruh Inflasi, CAR, FDR, BOPO, dan NPF Terhadap Profitabilitas Perbankan Syariah. ASSETS, Volume 6, Nomor 2, Desember 2016: 296-3.

Ubaidillah. (2016). Analisis Faktor-Faktor yang mempengaruhi Profitabilitas Bank Syariah di Indonesia. el-JIZYA Jurnal Ekonomi Islam (Islamic Economics Journal) Vol.4, No.1 Januari - Juni 2016 ISSN 2354 - 905X.

Wibisono, Muhammad Yusuf., Wahyuni, Salamah Pengaruh CAR, NPF, BOPO, FDR, terhadap ROA yang dimediasi oleh NOM. Jurnal Bisnis \& Manajemen Vol. 17, No. 1, $2017: 41-62$

Yusuf, Muhammad (2017). Dampak Indikator Rasio Keuangan terhadap Profitabilitas Bank Umum Syariah di Indonesia. Jurnal Keuangan dan Perbankan, Vol 13 No. 2 Juni 2017: $141-151$

Yusuf , Muhammad Yasir dan Mahriana, Wan Sri. (2016). Faktor-Faktor Yang Mempengaruhi Tingkat Profitabilitas Bank Pembiayaan Rakyat Syariah (BPRS) Di Aceh. IQTISHADIA Vol. 9, No. 2, 2016, 246-275. P-

ISSN:1979-0724, E-ISSN: 2502-3993 